\title{
Profil Klinis dan Terapeutik Anak Hiperplasia Adrenal Kongenital Terkait Gizi Lebih dan Obesitas
}

\author{
Ivena Susanti, Jose RL Batubara, Najib Advani \\ Departemen Ilmu Kesehatan Anak Fakultas Kedokteran Universitas Indonesia/Rumah Sakit Cipto \\ Mangunkusumo, Jakarta
}

\begin{abstract}
Latar belakang. Obesitas pada anak hiperplasia adrenal kongenital (HAK) dapat terjadi akibat penyakit dan terapi glukokortikoid. Di Indonesia, belum diketahui prevalensi gizi lebih dan obesitas pada anak HAK serta faktor-faktor yang berhubungan.

Tujuan. Mengetahui prevalensi gizi lebih dan obesitas anak HAK dan faktor yang berhubungan (faktor penyakit, faktor terapi, dan faktor umum).

Metode. Uji potong lintang pada anak HAK yang berobat di RSCM dan RS lain di Jabodetabek selama Maret-Juni 2013. Pencatatan data klinis, analisis diet, dan pemeriksaan kadar 17-hidroksiprogesteron (17OHP) dilakukan pada setiap subjek.

Hasil. Empatpuluh sembilan subjek-38 perempuan dan 11 laki-laki, rentang usia 0,4-18,3 tahun-memenuhi kriteria inklusi dan eksklusi. Subjek tipe salt wasting (SW) 79,6\% dengan median usia awal terapi 2,5 tahun lebih muda dibandingkan kelompok non-SW. Rerata dosis hidrokortison 17,2 (SB 6,4) mg/m $/ \mathrm{m}^{2} / \mathrm{hari}$ dan median durasi terapi 5,7 (rentang 0,1-18,3) tahun. Sebagian besar subjek memiliki kontrol metabolik undertreatment (36/49) dengan median kadar 17-OHP 19 (rentang 0,2-876) nmol/L. Terdapat 19 subjek sudah pubertas, 6 di antaranya mengalami pubertas prekoks. Ditemukan prevalensi gizi lebih dan obesitas $5,3 \%$ pada kelompok usia balita dan $66,7 \%$ usia lebih dari 5 tahun. Subjek memiliki asupan gizi lebih dari $62,5 \%$. Subjek dengan usia lebih dari 5 tahun, sudah pubertas, atau mengalami pubertas prekoks lebih berisiko mengalami gizi lebih dan obesitas. Durasi terapi glukokortikoid berkorelasi sedang $(r=0,668$; $\mathrm{p}=0,000$ ) dengan indeks massa tubuh (IMT), sedangkan dosis terapi tidak menunjukkan korelasi dengan IMT.

Kesimpulan. Prevalensi gizi lebih dan obesitas pada anak HAK adalah 42,9\%. Subjek dengan usia lebih dari 5 tahun, sudah pubertas, atau mengalami pubertas prekoks lebih berisiko mengalami gizi lebih dan obesitas. Terdapat korelasi sedang antara durasi terapi glukokortikoid dengan IMT. Sari Pediatri 2014;16(3):201-9
\end{abstract}

Kata kunci: hiperplasia adrenal kongenital, obesitas, karakteristik, terapi glukokortikoid

Alamat korespondensi:

Dr. Ivena Susanti, SpA; Prof. Dr. Jose R.L Batubara, SpA(K), PhD. Divisi Endokrinologi RSUPN Dr. Cipto Mangunkusumo. Jl. Diponegoro 71, Jakarta. Telp. (021) 3100669. Email: theresia.ivena@gmail.com

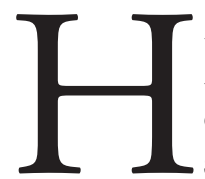
iperplasia adrenal kongenital (HAK) merupakan kelainan genetik akibat defisiensi enzim yang berperan dalam sintesis kortisol di korteks adrenal. Sekitar 
95\% kasus disebabkan defisiensi enzim 21-hidroksilase (21-OH) akibat mutasi pada gen CYP21A2. Manifestasi klinis HAK akibat defisiensi enzim 21-OH dibedakan menjadi tipe klasik, yaitu salt-wasting (SW) dan simple virilizing (SV), serta tipe non-klasik (NK) yang dapat asimtomatik atau disertai gejala kelebihan androgen saat dewasa. ${ }^{1-3}$

Terapi HAK meliputi terapi substitusi hormonal, yaitu glukokortikoid dan mineralokortikoid untuk mencegah krisis adrenal dan menekan sekresi androgen abnormal. Pemantauan terhadap penyakit dan efek samping terapi jangka panjang sangat diperlukan. ${ }^{1-4}$ Sekitar 45\% anak HAK mengalami gizi lebih, 16\% mengalami obesitas. Volkl dkk ${ }^{5}$ meneliti 89 anak HAK berusia 0,2-17,9 tahun dan mendapatkan indeks massa tubuh (IMT) berada pada rerata nilai simpang baku 0,88 , secara signifikan berada di atas 0 . Penyebab obesitas pada HAK bersifat multifaktorial, berkaitan dengan terapi glukokortikoid, kepatuhan pengobatan, usia kronologis, keterlambatan usia tulang, kadar leptin serum, penurunan tinggi akhir, obesitas orangtua, dan faktor umum lainnya. ${ }^{4-7}$ Obesitas meningkatkan risiko penyakit kardiovaskular dan sindrom metabolik. ${ }^{5,8,9}$

Di Indonesia, belum terdapat data mengenai prevalensi gizi lebih dan obesitas pada anak HAK dan faktor yang terkait, baik dari segi penyakit, terapi, dan faktor umum. Tujuan penelitian ini adalah untuk mengetahui prevalens gizi lebih dan obesitas pada anak HAK dan faktor-faktor yang terkait sehingga dapat dapat ditatalaksana lebih lanjut.

\section{Metode}

Penelitian desain potong lintang untuk mengetahui prevalensi gizi lebih dan obesitas pada anak HAK serta faktor yang berhubungan. Sampel diperoleh secara konsekutif dari anak HAK yang telah didiagnosis secara klinis dan laboratoris serta menjalani rawat jalan di Poliklinik Endokrinologi IKA FKUI RSCM dan RS lain di Jabodetabek selama periode Maret hingga Juni 2013. Pada setiap subjek dilakukan anamnesis, pemeriksaan fisis, analisis diet, pemeriksaan kadar 17OHP, dan penelusuran rekam medis.

Penentuan status gizi dilakukan berdasarkan kurva IMT WHO (World Health Organization). Untuk subjek usia 0-5 tahun didiagnosis gizi lebih apabila IMT lebih dari $z$-score 2, obesitas apabila IMT lebih dari $z$-score 3. Untuk usia lebih dari 5 tahun, gizi lebih
Tabel 1. Karakteristik demografi dan klinis subjek $(\mathrm{n}=49)$

\begin{tabular}{|c|c|c|}
\hline \multirow[t]{2}{*}{ Karakteristik } & \multicolumn{2}{|c|}{ Jumlah } \\
\hline & $\mathrm{n}$ & $\%$ \\
\hline \multicolumn{3}{|l|}{ Jenis kelamin } \\
\hline Laki-laki & 11 & 22,4 \\
\hline Perempuan & 38 & 77,6 \\
\hline \multicolumn{3}{|l|}{ Usia kronologis (tahun) } \\
\hline $0-5$ & 19 & 38,8 \\
\hline$>5$ & 30 & 61,2 \\
\hline \multicolumn{3}{|l|}{ Status pubertas } \\
\hline Sudah & 19 & 38,8 \\
\hline Belum & 30 & 61,2 \\
\hline \multicolumn{3}{|l|}{ Kesesuaian status pubertas } \\
\hline Sesuai & 43 & 87,8 \\
\hline Prekoks & 6 & 12,2 \\
\hline Terlambat & 0 & 0 \\
\hline \multicolumn{3}{|l|}{ Tipe HAK } \\
\hline Salt wasting (SW) & 39 & 79,6 \\
\hline \multicolumn{3}{|c|}{ Non-salt wasting (non-SW) } \\
\hline Simple virilizing (SV) & 9 & 18,4 \\
\hline Non-klasik & 1 & 2,0 \\
\hline \multicolumn{3}{|l|}{ Kontrol metabolik } \\
\hline Undertreatment & 30 & 61,2 \\
\hline Optimal & 19 & 38,8 \\
\hline Overtreatment & 0 & 0 \\
\hline \multicolumn{3}{|l|}{ Status gizi IMT } \\
\hline \multicolumn{3}{|l|}{$0-5$ tahun $(n=19)$} \\
\hline Buruk & 0 & 0 \\
\hline Kurang & 1 & 2,0 \\
\hline Baik & 13 & 26,5 \\
\hline Berisiko gizi lebih & 4 & 8,2 \\
\hline Lebih & 1 & 2,0 \\
\hline Obesitas & 0 & 0 \\
\hline \multicolumn{3}{|l|}{ Lebih dari 5 tahun $(\mathrm{n}=30)$} \\
\hline Buruk & 0 & 0 \\
\hline Kurang & 0 & 0 \\
\hline Baik & 10 & 20,4 \\
\hline Lebih & 11 & 22,4 \\
\hline Obesitas & 9 & 18,4 \\
\hline \multicolumn{3}{|l|}{ Tinggi badan } \\
\hline Tinggi & 0 & 0 \\
\hline Normal & 40 & 81,6 \\
\hline Pendek & 9 & 18,4 \\
\hline \multicolumn{3}{|l|}{ Asupan nutrisi } \\
\hline Tidak lebih & 18 & 36,7 \\
\hline Lebih & 30 & 62,5 \\
\hline \multicolumn{3}{|l|}{ Aktivitas fisis } \\
\hline Tidak aktif & 21 & 42,9 \\
\hline Aktif & 28 & 57,1 \\
\hline
\end{tabular}


apabila IMT lebih dari $z$-score 1 dan obesitas apabila IMT lebih dari $z$-score $2 .{ }^{10,11}$ Subjek dinyatakan sudah pubertas apabila status pubertas sesuai stadium Tanner 2 atau lebih. Kontrol metabolik dibedakan menjadi buruk (undertreatment), optimal, dan overtreatment. Kontrol metabolik buruk (undertreatment) ditandai dengan virilisasi progresif, interval kunjungan ke klinik lebih dari 6 bulan (untuk pasien berusia kurang dari 12 tahun) atau lebih dari 12 bulan (untuk usia lebih dari 12 tahun), kecepatan pertambahan tinggi badan pada z-score lebih dari 2 (diplot pada kurva WHO), kadar 17-OHP berkisar lebih dari $30 \mathrm{nmol} / \mathrm{L}$. Diartikan overtreatment apabila didapatkan tanda Cushingoid, kecepatan pertambahan tinggi badan pada $z$-score kurang dari -2 (diplot pada kurva WHO), kadar 17-OHP kurang dari $3 \mathrm{nmol} / \mathrm{L} .{ }^{5,12}$ Asupan nutrisi dikatakan lebih apabila melebihi recommended daily allowance (RDA). Aktivitas fisis dikatakan aktif apabila aktivitas fisis berdasarkan kategori usia memenuhi durasi waktu yang direkomendasikan Center for Disease Control (CDC) dan Australian National Recommendations for Physical Activities in Children. ${ }^{13,14}$

Data diolah menggunakan program SPSS 17. Penelitian ini telah mendapat persetujuan Komisi Etik Penelitian FKUI-RSCM.

\section{Hasil}

Selama Maret-Juni 2013, terdapat 30 anak HAK yang datang ke Poliklinik Endokrinologi IKA FKUIRSCM dan 19 lainnya diperoleh melalui kerjasama dengan Yayasan KAHAKI sehingga didapatkan total 49 subjek yang memenuhi kriteria inklusi dan eksklusi. Sebagian besar subjek berjenis kelamin perempuan (38/49) dengan rasio perempuan:laki-laki adalah 3,5:1 dan median usia 6,1 tahun (rentang: 0,4-18,3 tahun). Sebagian besar subjek (30/49) berusia lebih dari 5 tahun dan belum pubertas (30/49). Terdapat
6/11 anak laki-laki dan 13/38 anak perempuan sudah pubertas. Terdapat 3 anak perempuan dan 3 laki-laki yang mengalami pubertas prekoks dan tidak ada subjek yang mengalami pubertas terlambat.

Sebagian besar subjek (39/49) adalah HAK tipe SW. Tujuhbelas subjek didiagnosis HAK pada usia kurang dari 1 bulan. Kontrol metabolik yang buruk (undertreatment) didapatkan pada sebagian besar subjek (30/49). Median IMT subjek adalah 18,1 (rentang: 13,4-30,5) kg/m². Prevalensi subjek dengan gizi lebih dan obesitas adalah 42,9\%. Prevalensi gizi lebih dan obesitas lebih tinggi pada usia lebih dari 5 tahun $(66,7 \%)$ dibandingkan kelompok usia balita $(5,3 \%)$. Subjek dengan perawakan pendek 9 orang, 4 di antaranya memiliki gizi lebih atau obesitas. Mayoritas subjek (30/49) memiliki asupan nutrisi lebih, yaitu rerata $109,3 \%$ RDA (SB 19,9) dan aktif beraktivitas fisis (28/49) (Tabel 1).

Rerata dosis glukokortikoid adalah 17,2 (SB $6,4) \mathrm{mg} / \mathrm{m}^{2} /$ hari. Semua subjek mendapatkan hidrokortison. Tigapuluh tujuh subjek mendapatkan mineralokortikoid dengan median dosis 100 (rentang: 50-200) $\mathrm{mcg} /$ hari. Usia awal terapi antara 3 hari hingga 13 tahun, median 0,2 tahun. Durasi terapi glukokortikoid antara 0,1 hingga 18,3 tahun, median 5,7 tahun (Tabel 2).

Pasien dengan gizi lebih dan obesitas secara bermakna didapatkan lebih banyak pada kelompok usia lebih dari 5 tahun, sudah pubertas, memiliki status pubertas prekoks, atau mendapatkan asupan nutrisi lebih, dibandingkan kelompok yang tidak gizi lebih dan tidak obesitas (Tabel 3).

Durasi terapi glukokortikoid lebih lama didapatkan pada kelompok gizi lebih dan obesitas. Terdapat korelasi sedang antara durasi terapi glukokortikoid dengan IMT subjek $(\mathrm{r}=0,668 ; \mathrm{p}=0,000)$ (Tabel 4 dan 5).

Pada subjek dengan HAK tipe SW didapatkan usia awal terapi yang lebih dini dibandingkan dengan subjek dengan HAK tipe non-SW (Tabel 6).

Tabel 2. Karakteristik terapi

\begin{tabular}{lcc}
\hline Karakteristik terapi & Median & Rentang \\
\hline Dosis glukokortikoid $\left(\mathrm{mg} / \mathrm{m}^{2} /\right.$ hari) & 17,4 & $8-39,5$ \\
Dosis mineralokortikoid (mcg/hari, $\mathrm{n}=37)$ & 100 & $50-200$ \\
Usia awal terapi (tahun) & 0,2 & $0-13$ \\
Durasi terapi (tahun) & 5,7 & $0,1-18,3$ \\
Kadar 17-OHP (nmol/L) & 19 & $0,2-876$ \\
\hline
\end{tabular}


Tabel 3. Hubungan karakteristik klinis dengan status gizi

\begin{tabular}{|c|c|c|c|c|c|c|}
\hline \multirow[t]{2}{*}{ Karakteristik } & \multicolumn{2}{|c|}{$\begin{array}{c}\text { Tidak gizi lebih dan tidak } \\
\text { obesitas }\end{array}$} & \multicolumn{2}{|c|}{ Gizi lebih dan obesitas } & \multirow[t]{2}{*}{$\begin{array}{c}\mathrm{RR} \\
(\mathrm{IK} 95 \%)\end{array}$} & \multirow[t]{2}{*}{$\mathrm{p}^{\dagger}$} \\
\hline & $\mathrm{n}$ & $\%$ & $\mathrm{n}$ & $\%$ & & \\
\hline \multicolumn{7}{|l|}{ Jenis kelamin } \\
\hline Laki-laki & 4 & 36,4 & 7 & 63,6 & 0,33 & \multirow[t]{2}{*}{0,169} \\
\hline Perempuan & 24 & 63,2 & 14 & 36,8 & $(0,08-1,34)$ & \\
\hline \multicolumn{7}{|l|}{ Usia (tahun) } \\
\hline $0-5$ & 18 & 94,7 & 1 & 5,3 & 36 & \multirow[t]{2}{*}{0,000} \\
\hline$>5$ & 10 & 33,3 & 20 & 66,7 & $(4,19-309,67)$ & \\
\hline \multicolumn{7}{|l|}{ Status pubertas } \\
\hline Sudah & 3 & 15,8 & 16 & 84,2 & 0,04 & \multirow[t]{2}{*}{0,000} \\
\hline Belum & 25 & 83,3 & 5 & 16,7 & $(0,01-0,18)$ & \\
\hline \multicolumn{7}{|l|}{ Kesesuaian pubertas } \\
\hline Sesuai & 28 & 65,1 & 15 & 34,9 & 2,87 & \multirow[t]{2}{*}{$0,004^{*}$} \\
\hline Prekoks & 0 & 0 & 6 & 100 & $(1,91-4,32)$ & \\
\hline \multicolumn{7}{|l|}{ Tipe HAK } \\
\hline Salt wasting & 23 & 59 & 16 & 41 & 1,44 & \multirow[t]{2}{*}{$0,726^{*}$} \\
\hline Non-salt wasting & 5 & 50 & 5 & 50 & $(0,36-5,80)$ & \\
\hline \multicolumn{7}{|l|}{ Kontrol metabolik } \\
\hline Optimal & 13 & 68,4 & 6 & 31,6 & 0,46 & \multirow[t]{2}{*}{0,204} \\
\hline Undertreatment & 15 & 50 & 15 & 50 & $(0,14-1,54)$ & \\
\hline \multicolumn{7}{|l|}{ Asupan nutrisi } \\
\hline Tidak lebih & 16 & 88,9 & 2 & 11,1 & 12,67 & \multirow[t]{2}{*}{0,001} \\
\hline Lebih & 12 & 38,7 & 19 & 61,3 & $(2,46-65,17)$ & \\
\hline \multicolumn{7}{|l|}{ Aktivitas fisis } \\
\hline Aktif & 19 & 67,9 & 9 & 32,1 & 2,82 & \multirow[t]{2}{*}{0,080} \\
\hline Tidak aktif & 9 & 42,9 & 12 & 57,1 & $(0,87-9,10)$ & \\
\hline
\end{tabular}

Tabel 4. Hubungan karakteristik terapi dengan status gizi

\begin{tabular}{lccc}
\hline \multirow{2}{*}{ Karakteristik } & \multicolumn{2}{c}{ Median (rentang) } & \multirow{2}{*}{$\mathrm{p}$} \\
\cline { 2 - 3 } & $\begin{array}{c}\text { Tidak gizi lebih dan } \\
\text { tidak obesitas }\end{array}$ & Gizi lebih dan obesitas & 0,571 \\
\hline Usia awal terapi (tahun) & $0,2(0-13)$ & $0,2(0-5)$ & 0,000 \\
Durasi terapi (tahun) & $3,7(0,1-12,3)$ & $7,9(2,4-18,3)$ & 0,284 \\
Dosis glukokortikoid (mg/m²/hari) & $16,6(4,8)^{*}$ & $18,1(8,1)^{*}$ & 0,281 \\
Dosis mineralokortikoid (mcg/hari) & $100(0-150)$ & $100(0-200)$ & 0,649 \\
Kadar 17-OHP (nmol/L) & $27,6(0,2-763)$ & $19(0,2-876)$ & \\
\hline
\end{tabular}

*Rerata (SB) 
Tabel 5. Korelasi antara IMT dengan usia awal terapi, dosis glukokortikoid, durasi terapi, kadar 17-OHP

\begin{tabular}{lcc}
\hline & \multicolumn{2}{c}{ IMT } \\
\cline { 2 - 3 } & Koefisien korelasi (r) & $\mathrm{p}$ \\
\hline Usia awal terapi & 0,135 & 0,356 \\
Dosis glukokortikoid & 0,123 & 0,399 \\
Durasi terapi & 0,668 & 0,000 \\
Kadar 17-OHP & $-0,059$ & 0,689 \\
\hline
\end{tabular}

Uji korelasi Spearman tahun, dan tipe NK usia 7,4 tahun. Keluhan utama terbanyak yang membuat subjek didiagnosis HAK adalah genitalia ambigu (27/49), dengan 17 subjek di antaranya didiagnosis pada usia kurang dari 1 bulan. Di Inggris, Khalid dkk ${ }^{17}$ melaporkan bahwa $89 \%$ anak HAK didiagnosis dalam 1 bulan pertama kehidupan dengan keluhan utama genitalia ambigu (75\%) dan krisis adrenal (25\%), 67\% krisis adrenal terjadi pada usia di atas 14 hari.

Tabel 6. Hubungan karakteristik klinis dan terapi dengan tipe HAK

\begin{tabular}{lccc}
\hline \multirow{2}{*}{ Karakteristik } & \multicolumn{2}{c}{ Median (rentang) } & \\
\cline { 2 - 3 } & $\begin{array}{c}\text { Salt wasting } \\
(\mathrm{N}=39)\end{array}$ & $\begin{array}{c}\text { Non-salt wasting } \\
(\mathrm{N}=10)\end{array}$ & $\mathrm{p}$ \\
\hline IMT $\left(\mathrm{kg} / \mathrm{m}^{2}\right)$ & $17,7(13,4-30,5)$ & $19,7(16,8-28)$ & 0,112 \\
Usia awal terapi (tahun) & $0,1(0-4)$ & $2,6(0-13)$ & 0,002 \\
Dosis glukokortikoid $\left(\mathrm{mg} / \mathrm{m}^{2} /\right.$ hari) & $16,7(6,6)^{*}$ & $19,4(5,4)^{*}$ & 0,244 \\
Durasi terapi (tahun) & $5,1(0,1-18,3)$ & $7,7(0,3-12,3)$ & 0,172 \\
Kadar 17-OHP (nmol/L) & $19,8(0,2-876)$ & $17,5(0,4-574)$ & 0,862 \\
\hline
\end{tabular}

*Rerata (SB)

\section{Pembahasan}

Sebagian besar literatur menyatakan bahwa pasien HAK memiliki IMT yang lebih tinggi dibandingkan populasi normal. Obesitas pada HAK dipengaruhi berbagai faktor, yaitu faktor penyakit, terapi glukokortikoid, serta faktor lain seperti yang didapatkan pada populasi bukan HAK. Pada anak HAK di Indonesia, penelitian mengenai karakteristik klinis dan terapi yang berhubungan dengan gizi lebih dan obesitas belum pernah dilakukan sehingga perlu dilakukan penelitian ini.

Rasio perempuan berbanding laki-laki adalah 3,5:1. Hal tersebut sesuai dengan penelitian sebelumnya, yaitu Widodo $^{15}$ 3,6:1, Volkl dkk ${ }^{8}$ 1,43:1, dan Cornean dkk $^{9}$ 1,75:1. Diagnosis HAK lebih sering ditegakkan pada anak perempuan karena tampilan klinis yang lebih jelas sehingga cenderung untuk didiagnosis lebih dini.

Terdapat 39 subjek HAK tipe SW (79,6\%) dan 10 subjek HAK tipe non-SW (20,4\%). Terapi lebih dini dan diagnosis didapatkan subjek tipe SW, yaitu pada median usia 0,1 (rentang: 0-4) tahun dibandingkan tipe non-SW pada median usia 2,5 (rentang: 0-13) tahun. Hal tersebut dapat terjadi karena pada tipe SW terjadi krisis adrenal pada usia bayi. Manoli $\mathrm{dkk}^{16}$ mendapatkan bahwa subjek tipe SW didiagnosis pada rerata usia kurang dari 2 bulan, tipe SV pada usia 3,8
Gangguan pubertas pada anak HAK dapat berupa pubertas prekoks maupun pubertas terlambat. Pubertas prekoks diklasifikasikan menjadi pubertas prekoks sentral dan perifer yang dapat terjadi pada pasien HAK yang terlambat didiagnosis atau dalam waktu lama memiliki kontrol metabolik yang buruk. ${ }^{2,18} \mathrm{Pada}$ penelitian ini, 19 dari 49 subjek sudah pubertas dengan status pubertas sebagian besar sesuai usianya. Hanya 6 subjek yang mengalami pubertas prekoks, terdiri atas 3 anak perempuan dan 3 laki-laki; 5 subjek dengan HAK tipe SW dan 1 non-SW. Lima subjek yang mengalami pubertas prekoks memiliki kontrol metabolik yang buruk. Pubertas terlambat dapat terjadi akibat hiperandrogen yang memengaruhi aksis hipotalamushipofisis-gonad sehingga menyebabkan siklus ovulasi ireguler dan terbentuknya kista ovarium. ${ }^{1-4}$ Pada penelitian ini, tidak ada subjek yang mengalami pubertas terlambat.

Sebagian besar subjek memiliki perawakan normal, tetapi terdapat 9 subjek dengan perawakan pendek dan tidak ada subjek dengan perawakan tinggi. Perawakan pendek ini tidak berhubungan dengan tipe HAK, dosis glukokortikoid, usia awal terapi, dan kesesuaian status pubertas. Etiologi perawakan pendek mungkin akibat familial karena tinggi anak masih berada dalam rentang tinggi potensi genetik. Meta-analisis oleh Eugster 
$\mathrm{dkk}^{19}$ mendapatkan rerata tinggi akhir subjek HAK lebih rendah 1,34 SB dibandingkan populasi normal (lebih pendek 1,24 SB pada perempuan dan 1,57 SB pada laki-laki). Tinggi akhir yang pendek dapat terjadi karena pertumbuhan yang cepat dan penutupan dini epifisis akibat kelebihan androgen. Faktor lain yang berpengaruh terhadap gangguan pertumbuhan pada anak HAK adalah keterlambatan terapi, kepatuhan pengobatan yang buruk, dosis glukokortikoid yang berlebihan, dan pubertas prekoks. ${ }^{16,18,20}$

Sebagian besar subjek penelitian memiliki status gizi baik $(45,8 \%)$, selanjutnya berisiko gizi lebih $(32,7 \%)$ dan obesitas (18,4\%). Anak dengan HAK cenderung memiliki IMT tinggi karena rasio massa lemak dibanding massa bebas lemak lebih tinggi dibandingkan anak normal, serta adanya peningkatan kadar leptin dan resistensi insulin seperti dilaporkan pada penelitian Charmandari dkk. ${ }^{21}$ Anak HAK dengan kontrol metabolik yang buruk juga cenderung mempunyai tinggi akhir yang lebih pendek. ${ }^{4,22}$ Tinggi akhir yang berkurang dengan disertai peningkatan berat badan akan meningkatkan nilai IMT.

Semua pasien HAK mendapatkan hidrokortison. Dosis rerata glukokortikoid yang diberikan adalah $17,2(\mathrm{SB} 6,4) \mathrm{mg} / \mathrm{m}^{2} /$ hari. Dosis tersebut lebih tinggi dibandingkan panduan tata laksana HAK, yaitu 10$15 \mathrm{mg} / \mathrm{m}^{2} /$ hari. $^{10,23}$ Pemantauan terapi pada pasien HAK seharusnya berdasarkan manifestasi klinis, kurva pertumbuhan, usia tulang, dan kadar $17-\mathrm{OHP} .^{1-4}$ Keterbatasan biaya menyebabkan pemeriksaan tersebut tidak rutin dikerjakan oleh sebagian besar pasien sehingga dapat menghasilkan kontrol metabolik yang buruk.

Median durasi terapi adalah 5,7 (rentang: 0,118,3) tahun. Perbedaan median durasi terapi terjadi karena adanya perbedaan tipe HAK dan median usia awal terapi (0,2 tahun). Terdapat 37 subjek yang mendapatkan mineralokortikoid dengan median dosis adalah $100 \mathrm{mcg}$ (rentang: 50-200 mcg/hari). Dua dari 10 anak tipe non-SW mendapatkan mineralokortikoid dengan dosis $50 \mathrm{mcg} /$ hari. Mineralokortikoid (fludrokortison) dapat diberikan pada anak HAK tipe non-SW karena memiliki efek glukokortikoid sehingga berperan dalam substitusi kortisol dan menekan kadar androgen. ${ }^{24}$

Prevalensi gizi lebih dan obesitas pada kelompok balita adalah 5,3\%. Angka tersebut lebih rendah apabila dibandingkan dengan data Riskesdas 2010, ${ }^{25}$ padahal anak HAK lebih berisiko mengalami gizi lebih dan obesitas. Hal tersebut dapat terjadi karena pengambilan sampel secara konsekutif sehingga tidak didapatkan distribusi usia yang merata. Sebaliknya, prevalensi gizi lebih dan obesitas kelompok usia lebih dari 5 tahun menunjukkan angka lebih tinggi dibandingkan data Riskesdas 2010. ${ }^{25}$ Pada penelitian ini, pasien berusia lebih dari 5 tahun lebih berisiko mengalami gizi lebih dan obesitas dibandingkan pasien balita. Finkielstain $\mathrm{dkk}^{26}$ menyatakan $35 \%$ anak HAK mengalami obesitas. Angka tersebut lebih tinggi 2 kali lipat dibandingkan prevalensi obesitas pada populasi Amerika Serikat (17\%). Prevalensi obesitas (18,4\%) juga lebih tinggi dibandingkan penelitian Volkl $\mathrm{dkk}^{5}$ (16\%). Pada anak HAK, Cornean $\mathrm{dkk}^{9}$ menyatakan adiposity rebound terjadi pada usia yang lebih muda (1,7 tahun) dibandingkan populasi normal yang mengalami adiposity rebound (5,5 tahun). Hal tersebut menyebabkan anak HAK pada usia 2,5-5,5 tahun mengalami peningkatan IMT, tebal lipat kulit, dan massa lemak yang bermakna.

Pasien yang sudah mengalami pubertas, termasuk pasien dengan pubertas prekoks, lebih berisiko mengalami gizi lebih dan obesitas. Studi oleh Ngunyen $\mathrm{dkk}^{20}$ menegaskan hubungan antara nilai IMT dengan usia menars yang lebih dini (7,2-9,1 tahun). Pada penelitian ini, di antara 6 subjek yang mengalami pubertas prekoks, 3 memiliki status gizi obesitas dan 3 gizi lebih.

Pada penelitian ini, tipe HAK, usia awal terapi, kontrol metabolik, dan dosis glukokortikoid tidak berhubungan dengan status gizi. Hubungan antara tipe HAK dengan status gizi diteliti oleh Goncalves $\mathrm{dkk}^{27}$ yang menyatakan bahwa IMT, lingkar pinggang, lingkar lengan atas, dan persentase massa lemak yang lebih tinggi pada pasien HAK tipe SV dibandingkan HAK tipe SW. Goncalves ${ }^{27}$ juga melakukan evaluasi antropometri menggunakan DEXA terhadap 28 anak HAK dibandingkan dengan kontrol dan mendapatkan pasien HAK tipe SV mempunyai nilai IMT dan persentase massa lemak yang lebih tinggi baik sebelum atau setelah pubertas. Penelitian ini menunjukkan hasil yang berbeda karena sebagian besar subjek memiliki kepatuhan pengobatan yang buruk.

Pada kelompok dengan gizi lebih dan obesitas didapatkan median durasi terapi yang lebih panjang dibandingkan kelompok tidak gizi lebih dan tidak obesitas. Durasi terapi menunjukkan korelasi sedang. Sementara itu, dosis glukokortikoid tidak menunjukkan 
korelasi dengan IMT, tetapi pada kelompok gizi lebih dan obesitas didapatkan rerata dosis glukokortikoid yang lebih tinggi dibandingkan kelompok tidak gizi lebih dan tidak obesitas. Studi awal Knorr dan de Lienau $^{28}$ menyatakan korelasi bermakna antara terapi hidrokortison overtreatment pada 2 tahun pertama kehidupan dengan obesitas pada dewasa muda. Volkl $\mathrm{dkk}^{5}$ juga melaporkan korelasi positif antara dosis hidrokortison dengan kenaikan IMT. Massa lemak yang tinggi berkaitan dengan efek glukokortikoid jangka panjang, sementara peningkatan massa bebas lemak dan resistensi insulin mengindikasikan efek kelebihan androgen jangka panjang. ${ }^{29}$

Kontrol metabolik tidak menunjukkan hubungan dengan status gizi. Mnif $\mathrm{dkk}^{4}$ juga melaporkan obesitas pada berbagai status kontrol metabolik, yaitu 1 pasien dengan overtreatment dan 7 pasien undertreatment. Pemeriksaan lanjutan menggunakan DEXA menunjukkan peningkatan massa lemak tubuh terutama pada pasien undertreatment. ${ }^{4}$ Faktor lain yang tidak diteliti adalah kadar testosteron dan leptin yang berkorelasi positif terhadap kejadian obesitas pada pasien HAK. ${ }^{8,30,31}$

Faktor lain yang berkaitan dengan gizi lebih dan obesitas adalah asupan nutrisi dan aktivitas fisis. Asupan nutrisi yang berlebihan berhubungan dengan terjadinya gizi lebih dan obesitas. Sebagian besar subjek $(62,5 \%)$ mendapatkan asupan nutrisi yang melebihi RDA. Rerata persentase asupan nutrisi $117,3 \%$ pada kelompok gizi lebih dan obesitas. Asupan nutrisi yang berlebihan ini menyebabkan gizi lebih dan obesitas pada anak HAK. Tidak didapatkan hubungan antara aktivitas fisis dengan gizi lebih dan obesitas. Meskipun demikian, sebagian besar subjek dengan gizi lebih dan obesitas memiliki aktivitas fisis yang tidak aktif. Padahal, Ekelund $\mathrm{dkk}^{32}$ mengatakan dalam studi observasionalnya bahwa aktivitas fisis dapat menurunkan IMT.

Ketidaklengkapan data rekam medis, termasuk riwayat penyakit, status antropometris (berat dan tinggi badan), kurva pertumbuhan, dosis glukokortikoid dan mineralokortikoid yang diberikan menjadi keterbatasan penelitian. Pada pengisian kuesioner terdapat kelemahan, berupa recall bias mengenai riwayat penyakit pasien. Recall bias didapatkan juga dalam analisis diet. Faktor genetik-konstitusional, tingkat sosial ekonomi keluarga, berat lahir, dan asupan nutrisi perinatal tidak dievaluasi sehingga dapat menjadi faktor perancu hubungan antar variabel yang diteliti.

\section{Kesimpulan}

Prevalensi gizi lebih dan obesitas pada anak HAK 42,9\%. Pada usia balita, prevalensi gizi lebih dan obesitas 5,3\%, sedangkan pada usia lebih dari 5 tahun $66,7 \%$. Mayoritas subjek berjenis kelamin perempuan, berusia lebih dari 5 tahun, memiliki asupan nutrisi lebih, dan aktif beraktivitas fisis. Mayoritas subjek adalah HAK tipe SW, belum pubertas, dan terdapat 6 dari 19 anak yang sudah pubertas mengalami pubertas prekoks. Median usia awal terapi 0,2 tahun (rentang: 0-13) tahun dan median durasi terapi 5,7 (rentang: 0,1-18,3) tahun. Rerata dosis glukokortikoid 17,2 (SB 6,4) $\mathrm{mg} / \mathrm{m}^{2} /$ hari. Sebagian besar subjek dengan kontrol metabolik undertreatment, sesuai dengan kadar 17-OHP pada median 19 (rentang: 0,2-876) $\mathrm{nmol} / \mathrm{L}$. Terdapat korelasi sedang antara durasi terapi dengan IMT subjek $(r=0,668 ; p=0,000)$. Subjek dengan usia lebih dari 5 tahun, sudah pubertas, mengalami pubertas prekoks, atau mendapatkan asupan nutrisi lebih berisiko mengalami gizi lebih dan obesitas. Tidak terdapat hubungan antara jenis kelamin, aktivitas fisis, tipe HAK, usia awal terapi, dosis glukokortikoid, kontrol metabolik dengan gizi lebih dan obesitas pada anak HAK.

\section{Daftar pustaka}

1. American Academy of Pediatrics. Technical report: congenital adrenal hyperplasia. Pediatrics 2000;106;15118 .

2. Pulungan AB, Siregar CD, Aditiawati, Soenggoro EP, Triningsih E, Suryawan IWB, dkk. Korteks adrenal dan gangguannya. Dalam: Batubara JRL, Tridjaja B, Pulungan $\mathrm{AB}$, penyunting. Buku ajar endokrinologi anak. Edisi ke-1. Jakarta: Badan Penerbit Ikatan Dokter Anak Indonesia;2010.h.251-95.

3. Speiser PW, Azziz R, Baskin LS, Ghizzoni L, Hensle TW, Merke DP, dkk. Congenital adrenal hyperplasia due to steroid 21-hydroxylase deficiency: an endocrine society clinical practice guideline. J Clin Endocrinol Metab 2010;95:4133-60.

4. Mnif MF, Kamoun M, Mnif F, Charfi N, Kallel N. Long-term outcome of patients with congenital adrenal hyperplasia due to 21-hydroxylase deficiency. Am J Med Sci 2012;20:1-10.

5. Volkl TM, Simm D, Beier C, Dorr HG. Obesity among children and adolescents with classic congenital adrenal 
hyperplasia due to 21-hydroxylase deficiency. Pediatrics 2006;117:98-105.

6. Arlt W, Willis DS, Wild SH, Krone N, Doherty EJ, Hahner S, dkk. Health status of adults with congenital adrenal hyperplasia: a cohort study of 203 patients. J Clin Endocrinol Metab 2010;95:5110-21.

7. Reisch N, Arlt W, Krone N. Health problems in congenital adrenal hyperplasia due to 21-hydroxylase deficiency. Horm Res Paeditr 2011;76:73-85.

8. Volkl TM, Simm D, Korner A, Rascher W, Kiess W, Kratzsch J, dkk. Does an altered leptin axis play a role in obesity among children and adolescents with classical congenital adrenal hyperplasia due to 21-hydroxylase deficiency? Eur J Endocrinol 2009;160:239-47.

9. Cornean RE, Hindmarsch PC, Brook CG. Obesity in 21-hydroxylase deficient patients. Arch Dis Child 1998;78:261-3.

10. de Onis M, Onyango A, Borghi E, Siyam A, Pinol A, Garza C, dkk. WHO child growth standards method and development. France: WHO; 2006.h.229-62.

11. de Onis, Onyango AW, Borghi E, Siyam A, Nishida C, Siekmann J. Development of a WHO growth reference for school-aged children and adolescents. Bull WHO 2007;85:660-5.

12. Dauber A, Kellogg M, Majzoub JA. Monitoring of therapy in congenital adrenal hyperplasia. Clin Chemist 2010;56:1245-51.

13. Centers for Disease Control and Prevention. The physical activity guidelines for children and adolescents. Diakses pada tanggal 17 Februari 2013. Diunduh dari: http:// www.cdc.gov/physicalactivity/everyone/guidelines/children.html.

14. Australian Government Department of Health and Ageing. National recommendations for physical activities in children. Diakses pada tanggal 17 Februari 2013. Diunduh dari: http://www. health.gov.aulinternet/ main/publishing.nsflcontent/health-pubhlth-strateg-phys-actguidelines\#rec_O_18.

15. Widodo AD. Karakteristik densitas tulang anak dengan hiperplasia adrenal kongenital yang mendapat terapi glukokortikoid, tesis. Jakarta: Fakultas Kedokteran Universitas Indonesia, 2010.

16. Manoli I, Gantenbein K, Voutetakis A, Christidi MM, Voutetakis D. Early growth, pubertal development, body mass index and final height of patients with congenital adrenal hyperplasia: factors influencing the outcome. Clin Endocrinol 2002;57:669-76.

17. Khalid JM, Oerton JM, Dezateux C, Hindmarsh PC, Kelnar CJ, Knowles RL. Incidence and clinical features of congenital adrenal hyperplasia in Great Britain. Arch
Dis Child. 2012;97:101-6.

18. Carel JC, Leger J. Precocious puberty. N Engl J Med 2008;358-2366-77.

19. Eugster EA, Dimeglio LA, Wright JC, Freidenber GR, Seshadri R, Pescovitz OH. Height outcome in congenital adrenal hyperplasia caused by 21-hydroxylase deficiency: a meta-analysis. J Pediatr 2001;138:26-32.

20. Ngunyen ATT, Brown JJ, Warne GL. Growth in congenital adrenal hyperplasia. Indian J Pediatr 2006;73:89-93.

21. Charmandari E, Weise M, Bornstein SR, Eisenhofer G, Keil MF, Chrousos GP, dkk. Children with classic congenital adrenal hyperplasia have elevated serum leptin concentrations and insulin resistance: potential clinical implications. J Clin Endocrinol Metab 2002;87:211420.

22. Mooij CF, Kroese JM, Claahsen-van der Grinten H, Tack CJ, Hermus ARMM. Unfavourable trends in cardiovascular and metabolic risk in paediatric and adult patients with congenital adrenal hyperplasia?. Clin Endocrinol 2010;73:137-46.

23. Joint LWPES/ESPE CAH Working Group 2002. Consensus statement on 21-hydroxylase deficiency from The Lawson Wilkins Pediatric Endocrine Society and The European Society for Pediatric Endocrinology. J Clin Endocrinol Metab 2022;87:4048-53.

24. Claahsen-van der Grinten HL, Stikkelbroeck NMML, Otten BJ, Hermus ARMM. Congenital adrenal hyperplasia-pharmacologic interventions from the prenatal phase to adulthood. Pharmacol Ther 2011;132:1-14.

25. Depkes RI. Riset kesehatan dasar 2010. Diakses pada tanggal 5 Januari 2013. Diunduh dari: http://www.litbang. depkes.go.id/sites/download/buku_laporan/lapnas_riskesdas2010/ Laporan_riskesdas_2010.pdf.

26. Finkielstain GP, Kim MS, Sinaii N, Nishitani M, Ryzin CV, Hill SC, dkk. Clinical characteristics of a cohort of 244 patients with congenital adrenal hyperplasia. J Clin Endocrin Metab 2012;97:1-10.

27. Goncalves EM, de Lemos-Marini SHV, de Mello MP, Baptista MT, D’Souza-Li LF, Baldin AD, dkk. Impairment in anthropometric parameters and body composition in females with classical 21-hydroxylase deficiency. J Pediatr Endocrinol Metab 2009;22:51929.

28. Knorr D, de Lienau H. Persistent obesity and short final height after corticoid overtreatment for congenital adrenal hyperplasia $(\mathrm{CAH})$ in infancy. Acta Paediatr Japon 1988;30:89-92.

29. Williams RM, Deeb A, Ongt KK, Bich W, Murgatroyd 
PR, Hughes IA, dkk. Insulin sensitivity and body composition in children with classical and nonclassical congenital adrenal hyperplasia. Clin Endocrinol 2010;72:155-60.

30. Volkl TMK, Simm D, Komer A, Kiess W, Kratzsch J, Dorr HG. Adiponectin levels are high in children with classic congenital adrenal hyperplasia $(\mathrm{CAH})$ due to 21-hydroxylase deficiency. Acta Paediatr 2009;98:88591.

31. Hui JZ, Jun Y, Man NZ, Chang QL, Min X, Xue JL, dkk. Metabolic disorders in newly diagnosed young adult female patients with simple virilizing 21-hydroxylase deficiency. Endocrine 2010;38:260-5.

32. Ekelund U, Sardinha LB, Anderssen SA, Harro M, Franks PW, Brage S, dkk. Associations between objectively assessed physical activity and indicators of body fatness in 9-to 10-y-old European children: a population-based study from 4 distinct regions in Europe (the European Youth Heart Study). Am J Clin Nutr 2004;80:584-90. 